\title{
AN EXTENSION OF THE KNOWN RANGE OF THE POOR-WILL IN SASKATCHEWAN
}

\author{
by Clive Elliott, Calgary, Alberta
}

Until recently there were only two records of the occurrence of the Poorwill (Phalaenoptilus nuttallii) in Saskatchewan. Both Mitchell (1924) and Potter (1943) tell of a Poor-will heard calling for two or three nights in June, 1905 by L. B. Potter at his ranch at Eastend in extreme southwestern Saskatchewan. It is significant that this was Potter's only record at the ranch in 40 years. A more curious record is that cited by Mitchell (1924) of a Poor-will seen at the south end of Last Mountain Lake in 1920 by C. H. Young. Young was assistant to $P$. A. Taverner, and at the time he and Taverner were visiting Mitchell's field camp. Museum records show that this was at Little Arm, west of Regina Beach, some time between June 18 and September 7. It should be noted that the higher portions of this area are sandy and arid, and that those were dry years.

On August 22, 1961 the first Poorwill specimen for Sazkatchewan was taken to the northwest of Eastend at Calf Creek in the Cypress Hills by B. McCorquodale and A. E. Swanston (Bard, 1961), and at that time at least six different birds were reported heard. At Calf Creek (8-8-22 w3) I collected a second specimen on July 15, 1964 (Beck, 1965).

In the summer of 1965 , while employed by the Saskatchewan Museum of Natural History, I found Poorwills in Saskatchewan in the Frenchman River area east of Val Marie, in the Cypress Hills as far west at least as the West Block ranger station, and in the Great Sand Hills east of Fox Valley. The dates of occurrence and the numbers recorded suggest that this species breeds in the province.

On June 25, 1965 I heard two Poorwills calling about 10:30 p.m. near Walker's ranch buildings located in the Frenchman River Valley about six miles west of the point where the river crosses the international boundary. On June 28 two Poor-wills were heard calling in Otter Creek valley about three miles northeast of Walker's ranch buildings, about 11:00 p.m. Again on July 2, two Poor-wills were heard near Walker's ranch buildings and attempts were made to call them in. Twice one came in and perched close by, but neither time was the bird seen, and hence it was not collected. The birds did not circle around or come very close as this species often does when its call is imitated.

Shortly after this I began work in the West Block of the Cypress Hills. On July 12, three Poor-wills were heard about 10:30 p.m. on the hillside immediately east of the West Block ranger station, located north of Fort Walsh near Battle Creek. On July 17 attempts were made to call in these birds, but none was heard calling that night, and none would answer or come to investigate. On July 18 a single Poor-will was heard calling on the southwest side of Battle Creek, about 400 yards southwe'st of the ranger station; but attempts to call in birds east of the ranger station were again unsuccessful. One bird was observed flying over, but did not come down to investigate, and none answered.

On July 23, I moved camp to the Great Sand Hills east of Fox Valley. Some time was spent calling that night, but no Poor-will's answered and none was observed. On July 24, however, my calls were answered about 10:00 p.m., and after calling and stalking the bird for about 15 minutes, I saw it flying low over the hilltops and dipping down between the hills, then it circled over me several times, coming as close as about four feet. After being shot at, it 
circled two more times, then disappeared. More calls from myself brought it back immediately, however, and I was able to collect the bird.

On July 26, about 10:00 p.m., while hiking through the sandhills looking for Kangaroo Rats, I kept up a steady series of Poor-will calls, and was answered by what was evidently a different bird about every quarter to half mile for a distance of about two miles. One bird was called in and it circled me in the same manner as the first, whereupon a shot was fired. It immediately flew around a nearby hill and began calling from a tall sage brush. Attempts to call it back were unsuccessful, and upon being approached, it flew about 300 yards and perched again. I continued calling and carefully approached to within about 150 yards of it, when it suddenly appeared circling close to me, and I was therefore able to collect a second specimen.

It may be of interest to note that the stomach of one of the Poor-wills collected contained 100 per cent moths, and that of the second nearly as high a percentage, with one or two beetles as well. A Common Nighthawk collected in the same area had no moths, but nearly 100 per cent beetles and flies in its stomach. The Nighthawks begin to be active much earlier in the evening than the Poor-wills, although many Nighthawks are still still flying when the Poor-wills begin to call. Much more data would be needed to form any conclusions, but this scant amount of information suggests the definite ecological difference which we would expect to find between the two species.

Considering the range over which the Poor-will is now known to occur, and looking for conditions of climate and vegetation similar to that in its known range, this bird should be looked for in the western part of Saskatchewan as far north at least as the South Saskatchewan River, as far west as the Alberta border, south to the international boundary, and east to Regina and the Killdeer "badlands." The Big Muddy area south of
Bengough would seem a likely habitat, but in three weeks spent there in June, 1965 I did not hear a Poorwill.

The known range of the Poor-will in Saskatchewan includes areas ranging in climate from very hot and dry, such as the Great Sand Hills and the Frenchman Valley, to relatively cool and humid, like the Cypress Hills.

It would be interesting to know whether the Poor-will has occurred in Saskatchewan for a long period of time, or whether it has extended its range only recently to include this province. Because it is active only late at night, it generally goes unnoticed by local people, and so its history here may be hard to trace. It was found in the Cypress Hills in Alberta in 1945 (Salt and Wilk, 1958), and has since been listed a's breeding in Alberta (A.O.U., 1957) though no mention is made in the latter publication of its occurrence in Saskatchewan.

I would like to thank Fred G. Bard, Director, Saskatchewan Museum of Natural History, for sponsoring the field work, and Miss Margaret Belcher for assisting in the preparation of this report.

\section{LITERATURE CITED}

American Ornithologists' Union. 1957. Checklist of North American birds. Fifth ed. 691 pp.

Bard, F. G. 1961. First Poor-will specimen for Saskatchewan taken. Blue Jay, $19: 172$.

Beck, W. H. 1965. Second Poor-will specimen for Saskatchewan. Blue Jay, $23: 82$.

Mitchell, H. H. 1924. Catalogue of the birds of Saskatchewan. Can. Field-Nat., $38: 101-$ 118.

Potter, L. B. 1943. Bird notes from southwestern Saskatchewan. Can. Field-Nat., 57 : 69-72.

Salt, W. R., and A. L. Wilk. 1958. The birds of Alberta. The Queen's Printer, Edmonton. $511 \mathrm{pp}$.

\section{CALL FOR ALBERTA BIRD RECORDS}

Alberta observers who have not yet submitted their 1965 records are urged to write at once for a supply of report slips to Dr. M. T. Myres, Alberta Bird Report, Dept. of Biology, University of Alberta, Calgary, at Calgary, Alberta. In order to have your observations used in the Alberta Bird Report 1965 it is essential that records be received on official forms a's soon as possible. 